\section{Alternatives to Benomyl for Management of Cercospora Leaf Spot on Turnip Greens}

\author{
Brian A. Kahn, ${ }^{1}$ John P. Damicone, ${ }^{2}$ and Raymond Joe Schatzer ${ }^{3}$ \\ Oklahoma State University, Stillwater, OK 74078
}

Additional index words. Brassica rapa, Cercospora brassicicola, fungicides, plant disease, copper hydroxide, azoxystrobin, tebuconazole, acibenzolar-S-methyl, basic copper sulfate

\begin{abstract}
Benomyl was compared with copper hydroxide, azoxystrobin, tebuconazole, acibenzolar-S-methyl, and basic copper sulfate for efficacy of cercospora leaf spot [incited by Cercospora brassicicola P. Henn] management on turnip greens [Brassica rapa $\mathbf{L}$. var. (DC.) Metzg. utilis]. Treatments included various application times and were evaluated in three field experiments over 2 years. The few yield effects that occurred were not consistent between years. Copper hydroxide and basic copper sulfate were not useful alternatives to benomyl due to a combination of phytotoxicity symptoms and ineffective disease control. Inconsistent results were observed with acibenzolar-S-methyl. A single, early application of tebuconazole greatly reduced cercospora leaf spot severity relative to the control in both years. Tebuconazole may be a good alternative to benomyl if a label can be obtained. Multiple (at least two) applications of azoxystrobin may be needed to achieve the same degree of cercospora leaf spot control as would result from a single properly timed application of benomyl. Although azoxystrobin is now labeled for turnip greens, grower costs will likely increase as a result of benomyl being discontinued. Chemical names used: methyl-1[(butylamino)carbonyl]-H-benzimidazol-2-ylcarbamate (benomyl); methyl (E)-2-\{2-[6-(2cyanophenoxy)pyrimidin-4-yloxy]phenyl\}-3-methoxyacrylate (azoxystrobin); alpha-[2-(4chlorophenyl)ethyl]-alpha-(1,1-dimethylethyl)-1 $H$-1,2,4-triazole-1-ethanol (tebuconazole); 1,2,3-benzothiadiazole-7-thiocarboxylic acid-S-methyl-ester (acibenzolar-S-methyl).
\end{abstract}

Turnip greens grown for processing are mechanically harvested in bulk. All foliage is removed above the cutting bar, and hand separation of unacceptable leaves is difficult and expensive(Sumner etal., 1991). Numerous fungi are pathogens of turnip foliage, and cercospora leaf spot (hereafter abbreviated CLS) is one of the more widespread foliar diseases (Sumner etal., 1978). Leaf spots cause discoloration and decay of the leaf petioles and blades, reducing product grade and value. Fields with severely diseased plants may be discounted or rejected by processors. Therefore, growers of turnip greens require tools for management of foliar diseases.

Some early studies on fungicidal control of leaf spotting diseases on turnip greens were cited by Sumner (1971). Sumner et al. (1991) later published a study including data that supported the efficacy of benomyl for

Received for publication 16 Dec. 2004. Accepted for publication 29 Jan. 2005. Approved for publication by the Director, Oklahoma Agricultural Experiment Station. This research was supported in part under project H-2026, and in part by a grant from the Southern Region Pesticide Impact Assessment Program. We thank Thomas Genoff and his family for their cooperation. The information given in this publication is for educational purposes only. Mention of a trademark, proprietary product, or vendor does not constitute a guarantee or warranty of the product, nor does it imply approval or disapproval to the exclusion of other products or vendors that may also be suitable.

${ }^{1}$ Professor, Dept. of Horticulture and Landscape Architecture, and corresponding author.

${ }^{2}$ Professor, Dept. of Entomology and Plant Pathology. ${ }^{3}$ Professor, Dept. of Agricultural Economics. leaf spot control on turnip greens. Benomyl was labeled for this use and became popular among growers. However, when the present study was initiated (1999), there was a high probability of cancellation of benomyl. At that time benomyl, copper hydroxide, and basic copper sulfate were the only fungicides labeled for foliar disease management on turnip greens in the United States. Subsequently, benomyl was discontinued by its manufacturer.

The objective of the present study was to identify possible alternatives to benomyl for management of CLS of turnip greens. We chose to examine the two labeled copper-based products and three different potential alternative materials: azoxystrobin, a strobilurin fungicide with a wide range of activity against various fungal species, low application rates, and a benign environmental profile (Dacol et al., 1998); tebuconazole, a systemic, sterol-inhibiting fungicide (Labrinos and Nutter, 1993); and acibenzolar-S-methyl, an activator of systemic acquired resistance to various plant pathogens (Oostendorp et al., 2001).

\section{Materials and Methods}

Two field experiments were conducted in 1999 , one at the Vegetable Research Station, Bixby, Okla. (hereafter called the Research Station), and the second at a cooperator's farm (Thomas Genoff) about $1.5 \mathrm{~km}$ to the south of the Research Station. A third experiment was conducted at the Research Station in 2000. The soil was a Severn very fine sandy loam [coarsesilty, mixed (calcareous), thermic Typic Udifluvent]. Plots consisted of beds $6 \mathrm{~m}$ in length on 2.5-m centers to minimize spray drift between treatments. Each bed contained four (Research Station) or five (Genoff's) rows.

'Alltop' turnip greens were seeded in plots on 30 Aug. 1999 and on 9 Sept. 2000. Weeds were controlled with preplant-incorporated trifluralin [2,6-dinitro- $N, N$-dipropyl-4-(trifluoromethyl) benzenamine] at $280 \mathrm{~g} \cdot \mathrm{ha}^{-1}$ (Research Station) or $420 \mathrm{~g} \cdot \mathrm{ha}^{-1}$ (Genoff's) and by hoeing. Nitrogen fertilizer (urea) was applied at $34 \mathrm{~kg} \cdot \mathrm{ha}^{-1}$ preplant-incorporated and again at $34 \mathrm{~kg} \cdot \mathrm{ha}^{-1}$ as a topdressing on 30 Sept. 1999 , and at $56 \mathrm{~kg} \cdot \mathrm{ha}^{-1}$ as a topdressing on 22 Sept. 2000, at the Research Station. Adequate $\mathrm{P}$ and $\mathrm{K}$ were available from fertilization of previous trials at the Research Station. A preplant-incorporated application of $43 \mathrm{~N}-19 \mathrm{P}-35 \mathrm{~K}\left(\mathrm{~kg} \cdot \mathrm{ha}^{-1}\right)$ was made at the Genoff's in 1999.

Nineteen treatments (plus a nonsprayed control) were evaluated as shown in Table 1. One rate was used for each chemical material as appropriate to each given material. The adjuvant Latron CS-7 (60\% blend of alkyl aryl polyethoxylate and sodium salt of alkylsulfonatedalkylate, $40 \%$ ingredients ineffective as spray adjuvants; BFR Products, Five Points, Calif.) was added at $2.4 \mathrm{~mL}$ per $2.8 \mathrm{~L}$ of spray mix for benomyl, azoxystrobin, acibenzolar-Smethyl, and tebuconazole. In 1999, treatments were broadcast through flat-fan nozzles (8003 VK) spaced $46 \mathrm{~cm}$ apart on a wheelbarrow sprayer that applied $337 \mathrm{~L} \cdot \mathrm{ha}^{-1}$ at $275 \mathrm{kPa}$ (36 gpa at 40 psi). In 2000, the nozzles were changed to $8002 \mathrm{VK}$, so the sprayer applied $309 \mathrm{~L} \cdot \mathrm{ha}^{-1}$ at $275 \mathrm{kPa}$ (33 gpa at $\left.40 \mathrm{psi}\right)$. Two to three applications were expected to be enough to establish a point of diminishing returns for most materials. Turnip greens are a short season crop, and the focus material (benomyl) could not be applied more than twice per season.

Natural infection was allowed to occur; the plots were not inoculated. Plots were irrigated by sprinklers to supplement rainfall based on subjective observations of plants and soils. Insects were controlled with approved pesticides.

Yield and quality were determined by harvesting $2.5 \mathrm{~m}$ from two middle rows per plot. Plants were cut by hand with knives at about $3 \mathrm{~cm}$ above soil level. Harvests occurred on 20 Oct. 1999 and 3 Nov. 2000 (Research Station) and 25 Oct. 1999 (Genoff's). Harvested leaves were bulked, weighed, mixed, and blindly sampled. Leaf spot incidence (the percentage of leaves infected) and severity (the percentage of leaf area infected) were assessed on 30 leaves per plot.

The experimental design was a randomized complete block with four replications. Data were evaluated with analysis of variance procedures of the Statistical Analysis System (SAS) (SAS Institute, 1999). An arcsin transformation was applied to percentage data containing frequent zeroes before analysis. Individual $t$ tests were calculated using least squares means with a PDIFF option to compare chemical treatments to the control. The same procedure was used to provide dose/response information among the various application strategies within each tested product. 
Table 1. Summary of treatments applied to turnip greens in 1999 and 2000.

\begin{tabular}{|c|c|}
\hline Chemical material and rate ${ }^{z}$ & Dates of application \\
\hline Benomyl (280 g.ha ${ }^{-1}$; from a $50 \mathrm{WP}$ at $\left.0.56 \mathrm{~kg} \cdot \mathrm{ha}^{-1}\right)$ & $\begin{array}{l}\text { 1999: } 24 \text { Sept.; or } 1 \text { Oct.; or } 24 \text { Sept. and } 7 \text { Oct. } \\
\text { 2000: } 4 \text { Oct.; or } 10 \text { Oct.; or } 4 \text { and } 17 \text { Oct. }\end{array}$ \\
\hline Copper hydroxide (1999: $1.73 \mathrm{~kg} \cdot \mathrm{ha}^{-1}$; from a 77WP at 2.24 & 1999: 24 Sept.; or 24 Sept. and 1 Oct.; or 24 Sept. and 1 and 7 Oct. \\
\hline $\mathrm{kg} \cdot \mathrm{ha}^{-1} ; 2000: 0.9 \mathrm{~kg} \cdot \mathrm{ha}^{-1}$; from a $53.8 \mathrm{DF}$ at $\left.1.68 \mathrm{~kg} \cdot \mathrm{ha}^{-1}\right)$ & 2000: 4 Oct.; or 4 and 10 Oct.; or 4,10 , and 17 Oct. \\
\hline Azoxystrobin $\left(167 \mathrm{~g} \cdot \mathrm{ha}^{-1}\right.$; from a & 1999: 24 Sept.; or 24 Sept. and 1 Oct.; or 24 Sept. and 1 and 7 Oct. \\
\hline $249 \mathrm{~g} \cdot \mathrm{L}^{-1} \mathrm{~F}$ at $\left.672 \mathrm{~mL} \cdot \mathrm{ha}^{-1}\right)$ & 2000: 4 Oct.; or 4 and 10 Oct.; or 4, 10, and 17 Oct. \\
\hline Acibenzolar-S-methyl (35 g.ha-1; from a 50WG at $\left.70 \mathrm{~g} \cdot \mathrm{ha}^{-1}\right)$ & $\begin{array}{l}\text { 1999: } 24 \text { Sept.; or } 24 \text { Sept. and } 1 \text { Oct.; or } 24 \text { Sept. and } 1 \text { and } 7 \text { Oct.; or } 24 \text { Sept. and 1, } 7 \text {, and } 14 \text { Oct. } \\
\text { 2000: } 4 \text { Oct.; or } 4 \text { and } 10 \text { Oct.; or } 4 \text { and } 10 \text { and } 17 \text { Oct.; or 4, 10, 17, and } 25 \text { Oct. }\end{array}$ \\
\hline Tebuconazole $\left(189 \mathrm{~g} \cdot \mathrm{ha}^{-1}\right.$; from a & 1999: 24 Sept.; or 1 Oct.; or 24 Sept. and 7 Oct. \\
\hline $431 \mathrm{~g} \cdot \mathrm{L}^{-1} \mathrm{~F}$ at $\left.438 \mathrm{~mL} \cdot \mathrm{ha}^{-1}\right)$ & 2000: 4 Oct.; or 10 Oct.; or 4 and 17 Oct. \\
\hline Basic copper sulfate $\left(2.48 \mathrm{~kg} \cdot \mathrm{ha}^{-1}\right.$; from a $36.9 \mathrm{DF}$ at $6.7 \mathrm{~kg} \cdot \mathrm{ha}^{-1}$ & $\begin{array}{l}\text { 1999: } 24 \text { Sept.; or } 24 \text { Sept. and } 1 \text { Oct.; or } 24 \text { Sept. and } 1 \text { and } 7 \text { Oct. } \\
\text { 2000: } 4 \text { Oct.; or } 4 \text { and } 10 \text { Oct.; or 4, 10, and } 17 \text { Oct. }\end{array}$ \\
\hline None (control) & -- \\
\hline
\end{tabular}

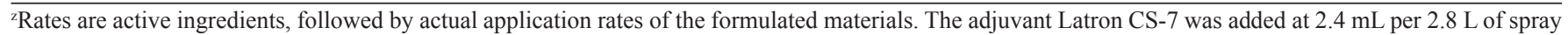
mix for benomyl, azoxystrobin, acibenzolar-S-methyl, and tebuconazole.

Table 2. Effects of Cercospora leaf spot management treatments on 'Alltop' turnip greens, Genoff Farm, Bixby, Okla., 1999.

\begin{tabular}{lccc}
\hline Treatment & Schedule & $\begin{array}{c}\text { Yield } \\
\left(\mathrm{Mg}^{\mathrm{y}} \mathrm{ha}^{-1}\right)\end{array}$ & $\begin{array}{c}\text { Phytotoxicity } \\
\text { incidence }(\%)\end{array}$ \\
\hline Benomyl & 1 & $66.3^{*}$ & 0.0 \\
Benomyl & 2 & 57.4 & 0.0 \\
Benomyl & 1,3 & 59.0 & 0.0 \\
Copper hydroxide & 1 & $69.3^{*} \mathrm{a}^{\mathrm{x}}$ & $0.1 \mathrm{~b}$ \\
Copper hydroxide & 1,2 & $47.0 \mathrm{~b}$ & $1.9^{* * *} \mathrm{a}$ \\
Copper hydroxide & $1,2,3$ & $58.1 \mathrm{ab}$ & $1.3^{* * *} \mathrm{a}$ \\
Azoxystrobin & 1 & 62.7 & 0.0 \\
Azoxystrobin & 1,2 & 51.5 & 0.0 \\
Azoxystrobin & $1,2,3$ & 66.1 & 0.0 \\
Acibenzolar-S-methyl & 1 & 59.4 & 0.0 \\
Acibenzolar-S-methyl & 1,2 & 56.7 & 0.0 \\
Acibenzolar-S-methyl & $1,2,3$ & 55.2 & 0.0 \\
Acibenzolar-S-methyl & $1,2,3,4$ & 55.4 & 0.0 \\
Tebuconazole & 1 & 51.1 & 0.0 \\
Tebuconazole & 2 & 63.2 & 0.0 \\
Tebuconazole & 1,3 & 61.1 & 0.0 \\
Basic copper sulfate & 1 & 53.6 & $0.2 \mathrm{c}$ \\
Basic copper sulfate & 1,2 & 49.1 & $5.8^{* *} \mathrm{a}$ \\
Basic copper sulfate & $1,2,3$ & 46.0 & $3.6^{* *} \mathrm{~b}$ \\
Control & --- & 51.5 & 0.0 \\
\hline 2ee Table & & & \\
\hline
\end{tabular}

${ }^{\mathrm{z} S e e}$ Table 1 for chemical application rates.

${ }^{y}$ Fungicide application dates: $1=24$ Sept., $2=1$ Oct., $3=7$ Oct., $4=14$ Oct.

"Within columns and within fungicide treatments, means followed by the same letter do not differ at $P \leq$ 0.05 by $t$ test. No letters appear when there are no significant differences.

${ }^{*, * *}$ Within columns, asterisks indicate means that differ from the control by $t$ test at $P \leq 0.05$ or 0.01 , respectively.

\section{Results}

Genoff's, 1999. Symptoms of CLS never developed at the Genoff farm, even though the test field was $<2 \mathrm{~km}$ from the Research Station plots where CLS was present. However, the Genoff's experiment provided an opportunity to examine treatment effects on yield and phytotoxicity. None of the treatments decreased yield relative to the control (Table 2). A single application of either benomyl or copper hydroxide on 24 Sept. increased yield relative to the control. Yield responded inconsistently to increasing doses of copper hydroxide, but no dose/response patterns for yield were evident with other fungicide treatments (Table 2). Single applications of copper hydroxide or basic copper sulfate did not increase phytotoxicity symptoms relative to the control, but multiple applications did (Table 2). None of the other chemical materials produced symptoms of phytotoxicity.

Research station, 1999. None of the treatments decreased yield relative to the control
(Table 3). A single application of tebuconazole on 4 Oct. increased yield relative to the control. A delayed single application of tebuconazole (on 10 Oct.) was detrimental to yield compared to the earlier single application on 4 Oct. No dose/response patterns for yield were evident with other fungicide treatments (Table 3 ). Only one treatment increased phytotoxicity symptoms relative to the control: three applications of basic copper sulfate resulted in a $12.5 \%$ incidence of phytotoxicity (other data not presented). Incidence of CLS was reduced relative to the control by two of the treatments with benomyl, all of the treatments with azoxystrobin, one of the treatments with acibenzolar-S-methyl, and two of the treatments with tebuconazole (Table 3). Most of the treatments reduced CLS severity relative to the control (Table 3 ).

Research station, 2000. Yield was decreased relative to the control by three or four applications of acibenzolar-S-methyl (Table 3). There was evidence of decreasing yield as the number of acibenzolar-S-methyl applications increased from one to three. No other treatments had significant effects on yield. Phytotoxicity could not be evaluated in 2000 due to scattered leaf burn from an unusually early freeze before harvest $\left(-5^{\circ} \mathrm{C}\right.$ on 9 Oct.). Incidence of CLS was reduced relative to the control by two of the treatments with benomyl, two of the treatments with azoxystrobin, the treatment involving four applications of acibenzolar-S-methyl, and two of the treatments with tebuconazole (Table 3). Each of these treatments, plus a few others, also reduced the severity of CLS relative to the control (Table 3).

\section{Discussion}

The few yield effects that occurred were not consistent between years. These yield effects may simply have been artifacts relative to the position of particular plots in the fields. However, use of tebuconazole has resulted in yield increases in peanuts (Arachis hypogaea L.) beyond those due solely to leaf spot control (Labrinos and Nutter, 1993). A single, early application of tebuconazole greatly reduced CLS severity relative to the control in both years of our study. There was no statistical benefit from a second application of tebuconazole, although the two-application treatment completely controlled CLS in 2000.

Multiple (at least two) applications of azoxystrobin also gave good results in both years of our study. However, a single properly timed application of benomyl would have been as effective. Protective and curative effects of azoxystrobin against Cercospora beticola Sacc. on sugar beets (Beta vulgaris L.) were reported by Anesiadis et al. (2003).

Inconsistent results were observed with acibenzolar-S-methyl. Oostendorp et al. (2001) noted that the spectra of fungal resistances activated by acibenzolar-S-methyl are very crop specific. Ziadi et al. (2001) reported that acibenzolar-S-methyl produced a dosage-dependent induced resistance response in cauliflower (Brassica oleracea L. Botrytis group) against downy mildew [incited by Peronospora parasitica (Pers. Fr.) Fr.]. However, these authors also reported that cauliflower seedlings treated with acibenzolar-S-methyl showed about a $22 \%$ reduction in growth. Similarly, Romero et al. (2001) noted that acibenzolar-S-methyl may reduce yield in pepper (Capsicum annuum L.). 


\begin{tabular}{|c|c|c|c|c|c|c|c|}
\hline \multirow{2}{*}{ Treatment } & \multirow{2}{*}{ Schedule ${ }^{\mathrm{y}}$} & \multirow{2}{*}{\multicolumn{2}{|c|}{$\frac{\text { Yield }}{\left(\mathrm{Mg}^{\prime} \cdot \mathrm{ha}^{-1}\right)}$}} & \multicolumn{4}{|c|}{ Leaf spot $(\%)$} \\
\hline & & & & \multicolumn{2}{|c|}{ Incidence } & \multicolumn{2}{|c|}{ Severity } \\
\hline Benomyl & 1 & 44.6 & 60.7 & $26.8 \mathrm{a}$ & $22.5 \mathrm{a}$ & $5.3^{* * *}$ & 4.7 \\
\hline Benomyl & 1,2 & 39.2 & 58.9 & $5.0^{* *} \mathrm{~b}$ & $4.0^{*} \mathrm{ab}$ & $1.0^{* * *}$ & $0.1^{* *}$ \\
\hline Copper hydroxide & 1 & 42.5 & 55.9 & 28.5 & 17.5 & $10.5^{*}$ & 2.2 \\
\hline Copper hydroxide & 1,2 & 42.6 & 55.4 & 26.5 & 39.2 & $9.5^{*}$ & 8.4 \\
\hline Copper hydroxide & $1,2,3$ & 36.8 & 57.3 & 35.0 & 13.2 & 14.6 & $1.3^{*}$ \\
\hline Azoxystrobin & $1,2,3$ & 41.1 & 60.2 & $6.8^{* *} \mathrm{ab}$ & $0.8^{* *}$ & $0.8^{* *}$ & $<0.1^{* *}$ \\
\hline Acibenzolar-S-methyl & 1 & 42.1 & $56.0 \mathrm{a}$ & $25.8^{*}$ & 15.0 & $9.0^{*} \mathrm{~b}$ & 2.4 \\
\hline Acibenzolar-S-methyl & 1,2 & 42.4 & $52.6 \mathrm{ab}$ & 37.2 & 22.5 & $19.1 \mathrm{a}$ & 1.3 \\
\hline Acibenzolar-S-methyl & $1,2,3$ & 38.5 & $48.4^{*} \mathrm{~b}$ & 27.2 & 6.8 & $15.4 \mathrm{ab}$ & $0.4^{*}$ \\
\hline Acibenzolar-S-methyl & $1,2,3,4$ & 42.1 & $48.4^{*} \mathrm{~b}$ & 23.2 & $6.5^{*}$ & $9.9^{*} \mathrm{~b}$ & $1.4^{*}$ \\
\hline Tebuconazole & 1 & $49.8^{* *} \mathrm{a}$ & 60.9 & $7.5^{* *} \mathrm{~b}$ & 6.5 & $1.8^{* *} \mathrm{~b}$ & $0.5^{*}$ \\
\hline Tebuconazole & 2 & $40.4 \mathrm{~b}$ & 62.7 & $23.5 \mathrm{a}$ & $3.2 *$ & $8.7^{*} \mathrm{a}$ & $0.8^{*}$ \\
\hline Control & -- & 39.6 & 56.0 & 45.2 & 32.5 & 19.3 & 10.1 \\
\hline
\end{tabular}

${ }^{2}$ See Table 1 for chemical application rates.

${ }^{y}$ Fungicide application dates: For $1999,1=24$ Sept., $2=1$ Oct., $3=7$ Oct., $4=14$ Oct. For $2000,1=4$ Oct., $2=10$ Oct., $3=17$ Oct., $4=25$ Oct.

${ }^{x}$ Within columns and within fungicide treatments, means followed by the same letter do not differ at $P \leq 0.05$ by $t$ test. No letters appear when there are no significant differences.

${ }^{* * * *}$ Within columns, asterisks indicate means that differ from the control by $t$ test at $P \leq 0.05$ or $P \leq 0.01$, respectively.

The two copper fungicides (copper hydroxide and basic copper sulfate) did not decrease incidence of CLS relative to the control at the Research Station in 1999 or 2000, regardless of frequency of application. The two copper fungicides were not useful as alternatives to benomyl due to a combination of phytotoxicity symptoms (1999) and lack of effective disease control.

Without yield increases, the expense of applications of fungicide cannot be recommended unless the production from untreated plots is unmarketable because of the severity of the disease. The question that must be addressed is how severe must the CLS be before the processor would reduce the price or reject the turnip greens. Turnip leaves showing more than $10 \%$ of the surface area discolored are nonsalable according to United States Department of Agriculture(USDA) standards (USDA, 1953). Severity of CLS in the control plots was at least $10 \%$ in both years at the Research Station, and in both years, the severity of CLS was significantly reduced by several of the treatments. Therefore, fungicide applications would have been justified.

The treatments that reduced CLS severity significantly from the control in both years were a late single application of benomyl; two applications of benomyl; one, two, or three applications of azoxystrobin; four applications of acibenzolar-S-methyl; and an early or late application or two applications of tebuconazole. Benomyl has been discontinued by its manufacturer. Azoxystrobin is now registered for use on turnip greens. Acibenzolar-S-methyl is not currently registered for use on turnip greens, but is registered for use on spinach (Spinacia oleracea L.) in Texas and California, and for control of downy mildew on the cole crop group (Brassica species). Tebuconazole is not currently registered for use on turnip greens, but is registered for use on peanuts. With no consistent yield differences, the most economic treatment would be a single application of the quality-maintaining chemical costing the least per hectare to apply. Given current registrations, azoxystrobin is the only alternative. Our data suggest that two applications of azoxystrobin may be needed to achieve the same degree of CLS control as a single properly timed application of benomyl. Thus, although growers have an effective alternative to benomyl for CLS management on turnip greens, their costs will likely increase.

\section{Literature Cited}

Anesiadis, T., G.S. Karaoglanidis, and K. TzavellaKlonari. 2003. Protective, curative and eradicant activity of the strobilurin fungicide azoxystrobin against Cercospora beticola and Erysiphe betae. J. Phytopathol. 151:647-651.

Dacol, L., M. Gibbard, M.O. Hodson, and S. Knight. 1998. Azoxystrobin: development on horticultural crops in Europe, p. 843-848. In: British Crop Protection Council. Brighton Crop Protection Conference: Pests and Diseases-1998. vol. 3: Proc. Intl. Conf., Brighton, U.K, 16-19
Nov. 1998.

Labrinos, J.L. and F.W. Nutter, Jr. 1993. Effects of a protectant versus a systemic fungicide on disease components of peanut late leaf spot. Plant Dis. 77:837-845.

Oostendorp, M. W. Kunz, B. Dietrich, and T. Staub. 2001. Induced disease resistance in plants by chemicals. Eur. J. Plant Pathol. 107:19-28.

Romero, A.M., C.S. Kousik, and D.F. Ritchie. 2001. Resistance to bacterial spot in bell pepper induced by acibenzolar-S-methyl. Plant Dis. 85:189-194.

SAS Institute. 1999. SAS/STAT user's guide, version 8. SAS Institute, Cary, N.C.

Sumner, D.R. 1971. Effect of leafspots on quality of turnip greens grown for processing. Plant Dis. Rptr. 55:540-543.

Sumner, D.R., N.C. Glaze, C.C. Dowler, and A.W Johnson. 1978. Foliar diseases of turnip grown for greens in intensive cropping systems. Plant Dis. Rptr. 62:51-55.

Sumner, D.R., D.K. Bell, D.A. Lillard, W.C. Hurst, P.A. Bush, and T. B. Brenneman. 1991. Leaf spot control, maneb, and ethylenethiourea residues in processed turnip greens treated with maneb. Plant Dis. 75:878-882.

United States Department of Agriculture. 1953. United States standards for grades of mustard greens and turnip greens. Agr. Mktg. Serv., Fruit and Veg. Div., Fresh Prod. Branch.

Ziadi, S., S. Barbedette, J.F. Godard, C. Monot, D. Le Corre, and. D. Silué. 2001. Production of pathogenesis-related proteins in the cauliflower (Brassica oleracea var. botrytis)-downy mildew (Peronospora parasitica) pathosystem treated with acibenzolar-S-methyl. Plant Pathol. 50:579-586. 